\title{
The assessment of the default risk for the banks of the Romanian banking system
}

\author{
Sorin Mădălin Vlad ${ }^{1}$, Gheorghe Ruxanda ${ }^{2}$ \\ ${ }^{1}$ The Doctoral School - Economic Cybernetics and Statistics, Bucharest Academy of Economic Studies, Bucharest, Romania \\ ${ }^{2}$ Department of Economic Cybernetics, Bucharest Academy of Economic Studies, Bucharest, Romania
}

Email address:

sorin_vlad10@yahoo.com (S. M. Vlad),ghrux@ase.ro (G. Ruxanda)

\section{To cite this article:}

Sorin Mădălin Vlad, Gheorghe Ruxanda. The Assessment of the Default Risk for the Banks of the Romanian Banking System. International Journal of Economics, Finance and Management Sciences. Vol. 3, No. 1, 2015, pp. 1-9. doi: 10.11648/j.ijefm.20150301.11

\begin{abstract}
By the current study we analyze the performance and plausibility of the empirical results provided by the [5] Duffie and Lando (2001) credit risk structural model with asymmetric information. By construction, such a model can allow the endogenous understanding of the default event (typically for a structural model), the plausibility of the default intensity existence (typically for a reduced form model), as well as the tractability of analytical formulas to be used at the estimation of the credit risk parameters. Under this framework we analyze the empirical model results, by the quantitative creditworthiness assessment of the banks from the Romanian banking system, as financial institutions of a low default portfolio. For the model implementation we apply a special calibration approach for the accounting white noise parameter. The empirical study is being conducted by the use of the banks' financial statement time series over the last Romanian economic cycle, during the period $2002-2012$.
\end{abstract}

Keywords: Default, Information Asymmetry, Default Probability, Default Intensity, Banks’ Assessment

\section{Introduction}

Compared to the classical structural models ([16] Merton (1974), [3] Black - Cox (1976)), the theoretical and methodological framework of the default prediction is missing the information concept and its progressive unfolding over time. This kind of structural models have the imbedded assumption that the information used at the model calibration and model use is fully available to the corporate debt investors (respectively, both the corporate debt investors and the firm's shareholders poses the same information level). By this methodological set up, the model inputs and parameters are presumptively known.

However, the rational of these models seems to be counterintuitive as far as the reality has been shown us that the firm's asset value, the asset volatility and asset return are not visible measures.

The financial statements that usually contain the proper information to assess the right firm's distance to default are difficult to be interpreted. These issues are furthermore reflected in the model results which are not fitting in the end with the economic sense of the empirical evidence.

[5] Duffie and Lando (2001) is the first paper approaching a credit risk structural model with the asymmetric information assumption imbedded, where the corporate debt investors cannot notice the real value of the firm's asset value. However, not perfectly informed, the corporate debt investors receive the firm's accounting asset value from the published financial statements at certain moments of time. These accounting asset values shall be considered as a benchmark for the real value of the firm's asset value over time. Besides, to overcome the information incompleteness, the model has the assumption that the default barrier of the firm can be known by the corporate debt investors.

In the next sections of the article we brief the key concepts behind [5] Duffie and Lando (2001) model and we focus in depth on the understanding of its performance tested with the empirical data of the banks from the Romanian banking system.

\section{The Model}

\subsection{The General Assumptions}

We present further in this section [5] Duffie and Lando (2001) model, as a methodological instrument in our empirical study. [5] Duffie and Lando (2001) model assumes that the default barrier of the firm is known to the stakeholders (corporate debt investors) of the firm, in the sense that they can infer it using the [11] Leland (1994) model. 
[11] Leland (1994) model provides a consistent approach of the estimation of the default barrier, this being thought as the result of the optimal capital structure allocation by the shareholders at the firm set up. The principle of the optimal capital structure is consistent with the shareholders incentive that the limited capital amount shall cover the firm's losses up to a certain maximum level. This loss level is achieved by the decrease of the firm's asset value below the debt value, up to the cross of the default barrier. Consequently, the default barrier is estimated such as at default time the firm's capital value to cover all its losses. With other words, when the asset value is equal to the default barrier, the shareholders would rather declare the firm insolvency instead of bringing additional money for covering higher losses.

For simplicity in the estimation of the optimal capital structure it is considered that the firm's asset process is time homogenous (the parameters of diffusion process shall not depend of the time passing therefore), this approach being argued by other authors such as [10] Fischer, Heinkel and Zechner (1989); [11], [12] Leland (1994, 1998); [1] Anderson, Pan and Sundaresan (1992); [2] Anderson and Sundareson (1996); [13] Leland and Toft (1996); [14] Mella-Barral and Perraudin (1997); [17] Uhrig (1998); [15] Mella - Barral (1999); [9] Fan and Sundareson (2000), also.

Using the default barrier estimated with [11] Leland (1994) model, [5] Duffie and Lando (2001) model provides then estimates related to: the conditional distribution of the firm's asset value given the incomplete observation of their real values, the associated default probabilities, the default intensity and the credit risk spreads.

\subsection{The Incomplete Information about the Firm's Asset Value}

We pay attention further on the capabilities of the corporate credit risk assessment from the corporate debt investors' side, who act on a bond or over-the-counter market. Consequently, after the corporate bond/ loan is issued/ granted, the corporate debt investors are not fully informed about the firm's creditworthiness. However they understand that under the framework of the optimal capital structure, the firm's shareholders will declare the firm's insolvency procedure only when its asset value will decrease to the optimal default barrier level $v^{*}$. Thus, even if the corporate debt investors cannot understand directly the firm's real asset value $V$, they receive at certain times $t_{1}, t_{2}, \ldots$, with $t_{i}<t_{i+1}$, the firm's financial statements. Let's consider that at each selected time, there is provided a new financial statement with new information about the firm's accounting asset value, denoted here by the process $\hat{V}_{t}$, where $\ln \hat{V}_{t}$ and $\ln V_{t}$ are normal distributed. The firm's real asset value is defined by $V_{t}=V_{0} e^{Z_{t}}$, with $Z_{t}=Z_{0}+m t+\sigma W_{t}$ and follows a diffusion process which is defined by a standard Brownian motion $W$, with asset volatility parameter $\sigma>0$ and drift $m \in(-\infty, \infty)$. Let it be $Y(t)=\ln \left(\hat{V}_{t} / V_{0}\right)=Z(t)+U(t)$ a process standing for the accounting asset value, where: $U(t)$ is an independent random variable that quantifies the accounting white noise around the real asset value, that is normal distributed and independent of $Z(t)$ (the assumption of independence is fulfilled without loss of generality, given that the normal law of $\ln \hat{V}_{t}$ and $\ln V_{t}$ ). Moreover at each time $t \in[0, \infty)$ the corporate debt investors notice if the shareholders have already declared the firm's insolvency. This means that the information filtration $\left(G_{t}\right)$ available to the corporate debt investors is defined by the following expression:

$$
G_{t}=\mathcal{A}_{t} \vee \sigma\left(N_{s}, s \leq t\right)=\sigma\left(\left\{Y\left(t_{1}\right), \ldots, Y\left(t_{n}\right), 1_{\{\tau \leq s\}}: 0 \leq s \leq t\right\}\right)
$$

for the highest $n$ such that $t_{n} \leq t$, where: $\tau=\tau\left(v^{*}\right)$ is the default time, $\left(\mathcal{A}_{t}\right)$ is the information filtration of the asset process, and $N_{s}=1_{\{\tau \leq s\}}$ is the pure jump process (with jump step of 1) that signals the default time appearance.

For simplicity, it is assumed that the firm's capital is not publically traded (there is no public equity subscription) and the firm's managers are not allowed for public trading the firm's debt on the stock exchange, because of the regulations regarding the forbiddance of the debt trading by the firm's internal staff.

These assumptions allow for the simplicity of the model's information filtration $\left(G_{t}\right)$ (defined by the expression (1)) from the secondary market, and avoid a complex approach with rational expectations and asymmetric information.

\subsection{The Model Outputs}

Furthermore, [5] Duffie and Lando (2001) model provides the analytical formulas for the probability of default, as presented below:

Let it be $Z_{0}=z_{0}$, the density $b\left(. \mid Y_{t}, z_{0}, t\right)$ of the $Z_{t}$ process (with $Z_{t}$ process stopping at the default time $\tau=\inf \left\{t: Z_{t} \leq \underline{-v}\right.$, $\left.\underline{v}=\ln \left(v^{*} / V_{0}\right)\right)$ conditioned by the unfolding of the accounting asset value information $Y_{t}=Z_{t}+U_{t}$ as of time $t$, is being defined by the following expression:

$$
b\left(x \mid Y_{t}, z_{0}, t\right)=\frac{\psi\left(z_{0}-\underline{v}, x-\underset{-}{v}, \sigma \sqrt{t}\right) \phi_{U}\left(Y_{t}-x\right) \phi_{Z}(x)}{\phi_{Y}\left(Y_{t}\right)}
$$

where $\Psi(z, x, \sigma \sqrt{t})=1-e^{\left(\frac{-2 z x}{(\sigma \sqrt{t})^{2}}\right)}$ and $\phi$ is the standard normal density.

Consequently, the firm's survival probability conditioned by the unfolding of the accounting asset value information $Y_{t}$ as of time $t$, is being defined by the following expression:

$$
P\left\{\tau>t \mid Y_{t}\right\}=\int_{\underline{v}}^{+\infty} b\left(z \mid Y_{t}, z_{0}, t\right) d z
$$

The next step is the achievement of the density $g\left(. \mid Y_{t}, z_{0}, t\right)$ of the real asset value process $Z_{t}$, which is conditioned by the non-appearance of the default time $\tau>t$ and by the unfolding of the accounting asset value information $Y_{t}$ as of time $t$ : 


$$
g\left(x \mid Y_{t}, z_{0}, t\right)=\frac{b\left(x \mid Y_{t}, z_{0}, t\right)}{\int_{\underline{v}}^{+\infty} b\left(z \mid Y_{t}, z_{0}, t\right) d z}
$$

The survival probability of the firm $p(t, s)=P\left\{\tau>s \mid G_{t}\right\}$, which is conditioned by the information filtration $\left(G_{t}\right)$, for a future time $s>t$, with $t<\tau$, is given by the next expression:

$$
p(t, s)=\int_{\underline{v}}^{\infty}(1-\pi(s-t, x-\underset{v}{v})) g\left(x \mid Y_{t}, z_{0}, t\right) d x
$$

where $\pi(t, y)$ is the probability of the first passage time that a Brownian motion of drift $m$ and volatility $\sigma$ to reach below a level $y=-x<0$ :

$$
\begin{aligned}
& \begin{array}{r}
\pi(t, x)=P\left\{m_{t}^{W} \leq-x\right\}=N\left(\frac{-x-m t}{\sigma \sqrt{t}}\right)+e^{-2 m x \sigma^{-2}} N\left(\frac{-x+m t}{\sigma \sqrt{t}}\right) \\
\bar{\lambda}=\frac{1}{2} \sigma^{2} \frac{1}{\int_{\underline{v}}^{+\infty} b\left(z \mid Y_{t}, z_{0}, t\right) d z} \frac{1}{\phi_{Y}\left(Y_{t}\right)} \times\left\{( \psi ( z _ { 0 } - v , 0 , \sigma \sqrt { t } ) - 1 ) \left(\frac{2\left(v-z_{-}\right.}{\sigma^{2} t}\right.\right. \\
\left.+\psi\left(z_{0}-v, 0, \sigma \sqrt{t}\right) \phi_{U}\left(Y_{t}-v\right) \phi_{Z}(v)\left(\frac{m t+z_{0}-v}{\sigma^{2} t}\right)\right\}
\end{array} \\
& \text { 3. The Assessment of the Banks from the } \\
& \text { Romanian Banking System }
\end{aligned}
$$

\section{The Assessment of the Banks from the Romanian Banking System}$$
\bar{\lambda}=\frac{1}{2} \sigma^{2} \frac{1}{\int_{\underline{v}}^{+\infty} b\left(z \mid Y_{t}, z_{0}, t\right) d z} \frac{1}{\phi_{Y}\left(Y_{t}\right)} \times\left\{( \psi ( z _ { 0 } - \underset { - } { v } , 0 , \sigma \sqrt { t } ) - 1 ) ( \frac { 2 ( v - z _ { 0 } ) } { \sigma ^ { 2 } t } ) \phi _ { U } \left(Y_{t}-\underset{-}{v} \phi_{Z}(v)+a \psi\left(z_{0}-\underset{-}{v}, 0, \sigma \sqrt{t}\right) \phi_{U}\left(Y_{t}-\underset{-v}{-v}\left(\frac{Y_{t}-v+a^{2} / 2}{a^{2}}\right) \phi_{Z}(v)\right.\right.\right.
$$

Besides, by the assumption of asymmetric information, [5] Duffie and Lando (2001) model proves both the existence of the default intensity concept because of the instant hazard perceived by the corporate debt investors in case of the firm's instant distress, as well as its analytical formula, as we present further in the next proposition.

Proposition 1: Let it be a process $\lambda$ defined by:

$$
\text { and } \begin{gathered}
\lambda_{t}(\omega)=\frac{1}{2} \sigma^{2} f_{x}(t, v, \omega) \text { for } 0<t \leq \tau, \\
\lambda(t)=0 \quad \text { for } t>\tau
\end{gathered}
$$

then $\lambda$ is a default intensity process for $\tau$ conditioned by the information filtration $\left(G_{t}\right)$. The proof can be found in [5] Duffie and Lando (2001) paper.

Using the above analytical formula of the default intensity, we derive its functional form, as presented by the next expression:
This chapter has the aim on the one hand to test the [5] Duffie and Lando (2001) model performance by numerical evidence (with empirical data), and on the other hand to provide a view related to the creditworthiness of the Romanian banks, which are assessed for the predictive period 2007 - 2013. The choice of such target portfolio has the explanation in its intrinsic economic behavior, namely: it is a low default portfolio (as per the best practice definition in the field), and consequently the default events appearance is very rare (with appearance at time intervals longer than an economic cycle). The special behavior of such kind of portfolio hardly constraints the modeling alternatives (for example a pure statistical model is not effective), letting opened the door for the use of the stochastic modeling.

\subsection{The Data}

The data sample for our study covers the banks' available annual financial statements for the years 2002 - 2012, as well as the daily time series of the Romanian government bonds quotations with annual coupon for the period $2007-2012$.

\subsection{The Parameters Calibration}

We calibrate the model parameters as follows: the firm's accounting asset value $\hat{V}$ is picked up from the banks' last financial statements; cash flow generation rate is the average operating profit over the last 5 years; annual asset return and annual asset volatility are calibrated based on the accounting asset value over the last 5 years; risk free interest rate is calibrated based the time series of government bonds with annual coupon; the Romanian tax rate is flat $16 \%$; the insolvency costs rate is considered $100 \%$; the volatility of the accounting noise is calibrated based on the intensity expression when the asset value is near to the default barrier.

\subsection{The Empirical Results}

To compute the banks' probabilities of default we estimate firstly their optimal default barrier level (by the use of [11] Leland (1994) model). The Table 1 presents the optimal default barrier depending of the each bank's financial statement information availability on different years.

The bank's accounting asset value of the previous year is higher than the default barrier level, the bank's distance to default is higher and consequently the expected default probability for the next year is lower.

By example, the Fig. 1 - 6 present the curves of the default probabilities for the first six banks of the Romanian banking system (by asset value).

According to these empirical results, the model consistently reacts to the technical assumptions, namely an increase in the accounting white noise volatility determines an increase in the default probability also. The default probabilities for the years 2007 and 2008 are low, in line with the last Romanian economic cycle. After that, each bank reacts earlier or later to the macroeconomic shocks propagated by the wave of the global financial crisis as well as the country economic and political environment. 
Table 1. The estimates of the banks' default barriers.

\begin{tabular}{|c|c|c|c|c|c|c|c|}
\hline \multicolumn{8}{|c|}{ Default Barrier, valid by the end of the year (\% of assets) } \\
\hline \multicolumn{8}{|c|}{ Predicted years } \\
\hline Bigger Banks & 2007 & 2008 & 2009 & 2010 & 2011 & 2012 & 2013 \\
\hline Banca Comerciala Romana & $54 \%$ & $56 \%$ & $79 \%$ & $65 \%$ & $39 \%$ & $65 \%$ & $60 \%$ \\
\hline BRD-Groupe Societe Generale Romania & $33 \%$ & $44 \%$ & $80 \%$ & $55 \%$ & $44 \%$ & $69 \%$ & $57 \%$ \\
\hline Banca Transilvania & & $56 \%$ & $57 \%$ & $34 \%$ & $29 \%$ & $58 \%$ & $96 \%$ \\
\hline CEC Bank & $39 \%$ & $53 \%$ & $96 \%$ & $89 \%$ & $61 \%$ & $57 \%$ & $55 \%$ \\
\hline UniCredit Tiriac Bank Romania & & & & & & $82 \%$ & $75 \%$ \\
\hline Raiffeisen Bank Romania & & $55 \%$ & $64 \%$ & $77 \%$ & $77 \%$ & $11 \%$ & $80 \%$ \\
\hline Alpha Bank Romania & $50 \%$ & $53 \%$ & $79 \%$ & $51 \%$ & $33 \%$ & $22 \%$ & $42 \%$ \\
\hline Bancpost Romania & & $35 \%$ & $71 \%$ & $56 \%$ & $25 \%$ & $44 \%$ & $24 \%$ \\
\hline
\end{tabular}

Table 1. The estimates of the banks' default barriers. (Continue)

\begin{tabular}{|c|c|c|c|c|c|c|c|}
\hline \multicolumn{8}{|c|}{ Default Barrier, valid by the end of the year (\% of assets) } \\
\hline \multicolumn{8}{|c|}{ Predicted years } \\
\hline Smaller Banks & 2007 & 2008 & 2009 & 2010 & 2011 & 2012 & 2013 \\
\hline Piraeus Bank Romania & $58 \%$ & $27 \%$ & $44 \%$ & $18 \%$ & $7 \%$ & $6 \%$ & $38 \%$ \\
\hline RBS Bank Romania & $61 \%$ & $52 \%$ & $89 \%$ & $48 \%$ & $22 \%$ & $14 \%$ & \\
\hline Intesa Sanpaolo Bank Romania & & & & $59 \%$ & $63 \%$ & $70 \%$ & $66 \%$ \\
\hline Credit Europe Bank Romania & & & & $29 \%$ & $13 \%$ & $8 \%$ & $13 \%$ \\
\hline Banca Comerciala Carpatica & & $41 \%$ & $45 \%$ & $45 \%$ & $28 \%$ & $46 \%$ & $25 \%$ \\
\hline OTP Bank Romania & $16 \%$ & $16 \%$ & $11 \%$ & $20 \%$ & $10 \%$ & $42 \%$ & $52 \%$ \\
\hline Eximbank Romania & $24 \%$ & $24 \%$ & $48 \%$ & $48 \%$ & $87 \%$ & $11 \%$ & $69 \%$ \\
\hline ProCredit Bank Romania & & $28 \%$ & $43 \%$ & $49 \%$ & $41 \%$ & $43 \%$ & $30 \%$ \\
\hline Bank Leumi Romania & & & & $54 \%$ & $39 \%$ & $38 \%$ & $23 \%$ \\
\hline Nextebank Romania & & $44 \%$ & $74 \%$ & $52 \%$ & $15 \%$ & $6 \%$ & \\
\hline
\end{tabular}

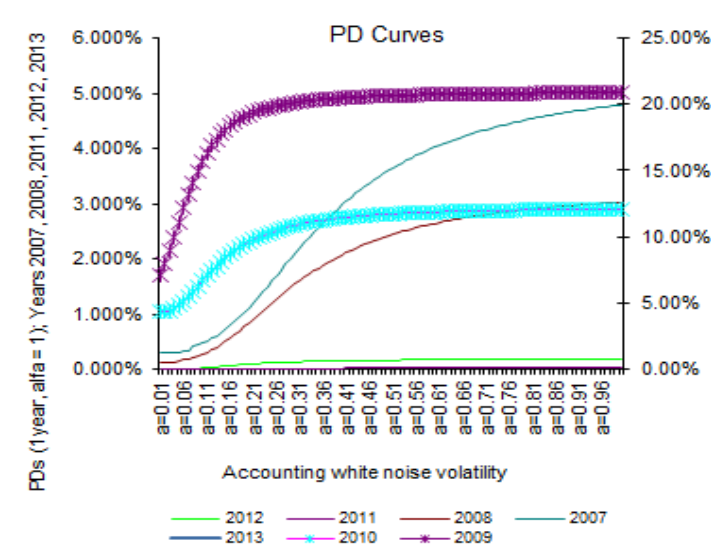

Figure 1. Banca Comerciala Romana.

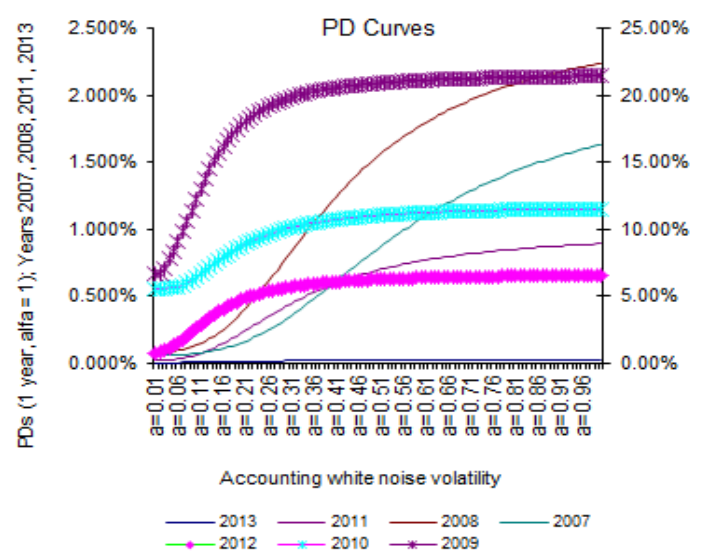

Figure 2. BRD Goup Societe Generale. Romania
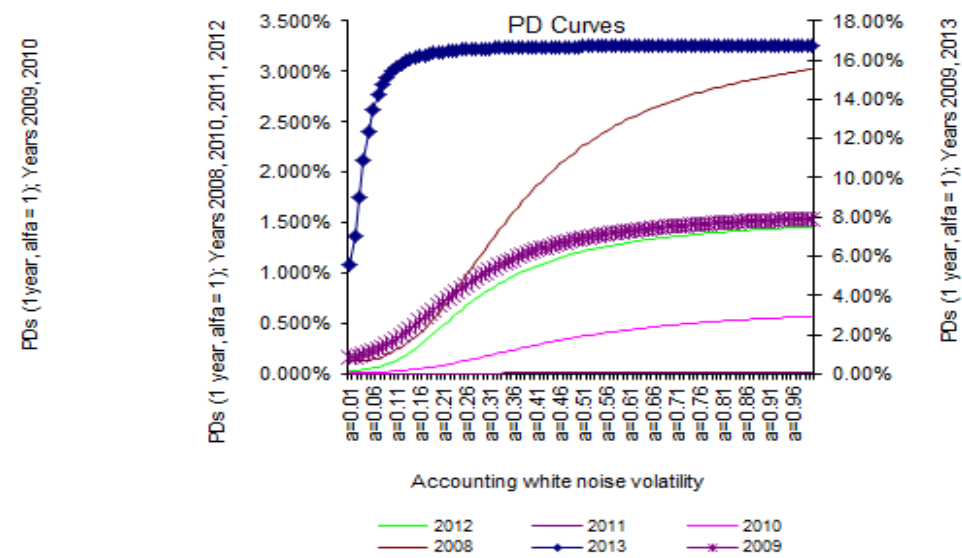

Figure 3. Banca Transilvania.
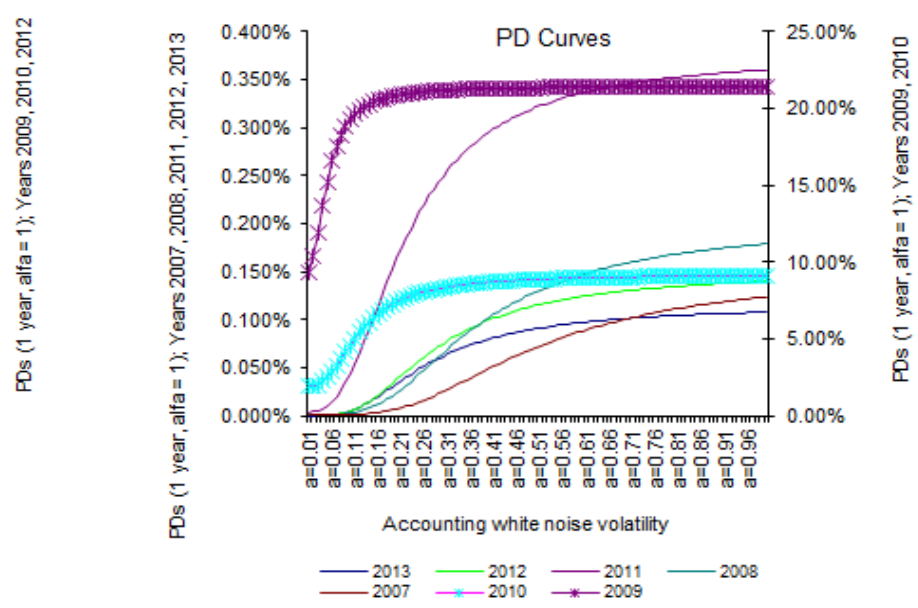

Figure 4. CEC Bank. 


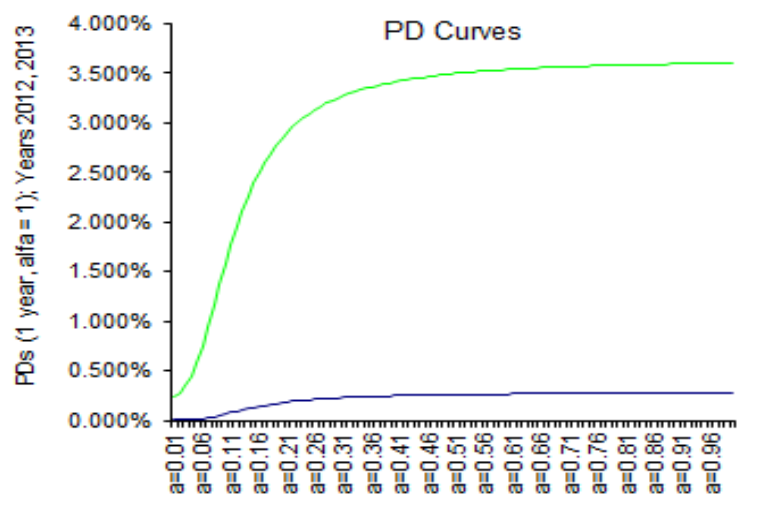

Accounting white noise volatility

$$
-2013 \quad 2012
$$

Figure 5. UniCredit Tiriac Bank. Romania

As a next step we perform the selection of the punctual default probability from the estimated curves. To do this, we estimate the accounting white noise volatility from the calibration of the default intensity expression with the asset values in the neighborhood of the default barrier. The Table 2 presents the calibrated values for the accounting white noise volatility.
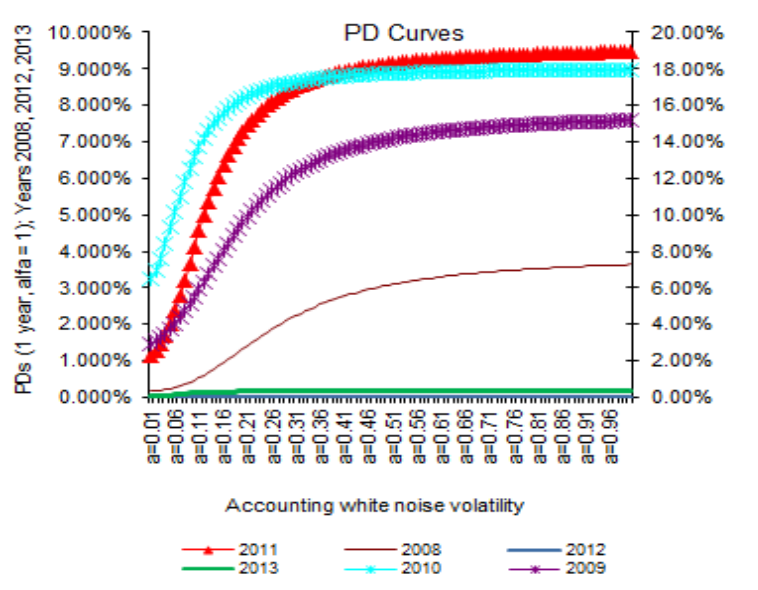

Figure 6. Raiffeisen Bank. Romania

Using the values of the accounting white noise volatility we estimate the punctual default probabilities with one year future expectation time horizon. The related results are presented in the Table 3. On all the analyzed banks, the expected default probabilities for the years 2009 and 2010 are the highest ones, the results being consistent with the economic reality from that period of the business cycle. After that the expected probabilities become progressively lower.

Table 2. The calibrated values of the accounting white noise volatility.

\begin{tabular}{|c|c|c|c|c|c|c|c|}
\hline \multicolumn{8}{|c|}{ The calibrated values of the accounting white noise volatility (\%) } \\
\hline \multicolumn{8}{|c|}{ Predicted years } \\
\hline Bigger Banks & 2007 & 2008 & 2009 & 2010 & 2011 & 2012 & 2013 \\
\hline Banca Comerciala Romana & $9 \%$ & $8 \%$ & $10 \%$ & $12 \%$ & $6 \%$ & $4 \%$ & $1 \%$ \\
\hline BRD-Groupe Societe Generale Romania & $12 \%$ & $10 \%$ & $8 \%$ & $16 \%$ & $9 \%$ & $8 \%$ & $4 \%$ \\
\hline Banca Transilvania & & $7 \%$ & $12 \%$ & $12 \%$ & $7 \%$ & $6 \%$ & $1 \%$ \\
\hline CEC Bank & $7 \%$ & $5 \%$ & $3 \%$ & $3 \%$ & $5 \%$ & $4 \%$ & $5 \%$ \\
\hline UniCredit Tiriac Bank Romania & & & & & & $3 \%$ & $3 \%$ \\
\hline Raiffeisen Bank Romania & & $9 \%$ & $13 \%$ & $10 \%$ & $6 \%$ & $1 \%$ & $2 \%$ \\
\hline Alpha Bank Romania & $9 \%$ & $6 \%$ & $7 \%$ & $8 \%$ & $7 \%$ & $10 \%$ & $7 \%$ \\
\hline Bancpost Romania & & $7 \%$ & $10 \%$ & $14 \%$ & $8 \%$ & $13 \%$ & $1 \%$ \\
\hline
\end{tabular}

Table 2. The calibrated values of the accounting white noise volatility. (Continue)

\begin{tabular}{|c|c|c|c|c|c|c|c|}
\hline \multicolumn{8}{|c|}{ The calibrated values of the accounting white noise volatility (\%) } \\
\hline \multicolumn{8}{|c|}{ Predicted years } \\
\hline Smaller Banks & 2007 & 2008 & 2009 & 2010 & 2011 & 2012 & 2013 \\
\hline Piraeus Bank Romania & $4 \%$ & $10 \%$ & $15 \%$ & $16 \%$ & $9 \%$ & $10 \%$ & $7 \%$ \\
\hline RBS Bank Romania & $8 \%$ & $6 \%$ & $6 \%$ & $11 \%$ & $5 \%$ & $4 \%$ & \\
\hline Intesa Sanpaolo Bank Romania & & & & $10 \%$ & $8 \%$ & $7 \%$ & $8 \%$ \\
\hline Credit Europe Bank Romania & & & & $29 \%$ & $21 \%$ & $9 \%$ & $4 \%$ \\
\hline Banca Comerciala Carpatica & & $9 \%$ & $20 \%$ & $16 \%$ & $17 \%$ & $10 \%$ & $6 \%$ \\
\hline OTP Bank Romania & $17 \%$ & $19 \%$ & $19 \%$ & $28 \%$ & $20 \%$ & $6 \%$ & $5 \%$ \\
\hline Eximbank Romania & $14 \%$ & $12 \%$ & $17 \%$ & $17 \%$ & $5 \%$ & $1 \%$ & $4 \%$ \\
\hline ProCredit Bank Romania & & $8 \%$ & $19 \%$ & $19 \%$ & $14 \%$ & $5 \%$ & $2 \%$ \\
\hline Bank Leumi Romania & & & & $14 \%$ & $14 \%$ & $14 \%$ & $1 \%$ \\
\hline Nextebank Romania & & $5 \%$ & $5 \%$ & $18 \%$ & $26 \%$ & $11 \%$ & \\
\hline
\end{tabular}


Table 3. The banks' Point-in-Time default probabilities.

\begin{tabular}{|c|c|c|c|c|c|c|c|}
\hline \multicolumn{8}{|c|}{ Point-in-Time PD (Default Probability, expected in 1 year) * } \\
\hline \multicolumn{8}{|c|}{ Predicted years } \\
\hline Bigger Banks & 2007 & 2008 & 2009 & 2010 & 2011 & 2012 & 2013 \\
\hline Banca Comerciala Romana & $0.44 \%$ & $0.22 \%$ & $15.70 \%$ & $7.43 \%$ & $0.03 \%$ & $0.03 \%$ & $0.03 \%$ \\
\hline BRD-Groupe Societe Generale Romania & $0.08 \%$ & $0.13 \%$ & $10.56 \%$ & $7.88 \%$ & $0.05 \%$ & $2.02 \%$ & $0.03 \%$ \\
\hline Banca Transilvania & & $0.15 \%$ & $1.97 \%$ & $0.03 \%$ & $0.03 \%$ & $0.06 \%$ & $5.55 \%$ \\
\hline CEC Bank & $0.03 \%$ & $0.03 \%$ & $11.91 \%$ & $2.02 \%$ & $0.03 \%$ & $0.03 \%$ & $0.03 \%$ \\
\hline UniCredit Tiriac Bank Romania & & & & & & $0.34 \%$ & $0.03 \%$ \\
\hline Raiffeisen Bank Romania & & $0.61 \%$ & $6.77 \%$ & $13.16 \%$ & $2.36 \%$ & $0.03 \%$ & $0.03 \%$ \\
\hline Alpha Bank Romania & $0.19 \%$ & $0.04 \%$ & $5.76 \%$ & $0.05 \%$ & $0.03 \%$ & $0.03 \%$ & $0.03 \%$ \\
\hline Bancpost Romania & & $0.03 \%$ & $5.52 \%$ & $4.09 \%$ & $0.03 \%$ & $0.85 \%$ & $0.03 \%$ \\
\hline
\end{tabular}

Table 3. The banks' Point-in-Time default probabilities. (Continue)

\begin{tabular}{|c|c|c|c|c|c|c|c|}
\hline \multicolumn{8}{|c|}{ Point-in-Time PD (Default Probability, expected in 1 year) * } \\
\hline \multicolumn{8}{|c|}{ Predicted years } \\
\hline Smaller Banks & 2007 & 2008 & 2009 & 2010 & 2011 & 2012 & 2013 \\
\hline Piraeus Bank Romania & $0.03 \%$ & $0.03 \%$ & $1.36 \%$ & $0.03 \%$ & $0.03 \%$ & $0.03 \%$ & $0.03 \%$ \\
\hline RBS Bank Romania & $0.50 \%$ & $0.03 \%$ & $14.13 \%$ & $1.10 \%$ & $0.03 \%$ & $0.03 \%$ & \\
\hline Intesa Sanpaolo Bank Romania & & & & $1.26 \%$ & $1.09 \%$ & $1.85 \%$ & $1.71 \%$ \\
\hline Credit Europe Bank Romania & & & & $7.06 \%$ & $0.10 \%$ & $0.03 \%$ & $0.03 \%$ \\
\hline Banca Comerciala Carpatica & & $0.04 \%$ & $6.18 \%$ & $2.53 \%$ & $0.44 \%$ & $0.23 \%$ & $0.03 \%$ \\
\hline OTP Bank Romania & $0.06 \%$ & $0.07 \%$ & $0.03 \%$ & $2.12 \%$ & $0.03 \%$ & $0.03 \%$ & $0.03 \%$ \\
\hline Eximbank Romania & $0.03 \%$ & $0.03 \%$ & $3.60 \%$ & $3.54 \%$ & $9.27 \%$ & $0.03 \%$ & $0.03 \%$ \\
\hline ProCredit Bank Romania & & $0.03 \%$ & $4.05 \%$ & $7.47 \%$ & $0.84 \%$ & $0.03 \%$ & $0.03 \%$ \\
\hline Bank Leumi Romania & & & & $4.31 \%$ & $0.61 \%$ & $0.39 \%$ & $0.03 \%$ \\
\hline Nextebank Romania & & $0.03 \%$ & $0.40 \%$ & $8.69 \%$ & $2.93 \%$ & $0.03 \%$ & \\
\hline
\end{tabular}

* Point-in-Time PD below $0.03 \%$ were capped at $0.03 \%$, as per Basel regulations

Table 4. The banks' Through-the-Cycle default probabilities and mapping to S\&P ratings.

\begin{tabular}{lllllllll}
\hline & Bigger Banks & & & & & & \\
\hline & $\begin{array}{l}\text { Banca } \\
\text { Comerciala } \\
\text { Romana }\end{array}$ & $\begin{array}{l}\text { BRD-Groupe Societe } \\
\text { Generale Romania }\end{array}$ & $\begin{array}{l}\text { Banca } \\
\text { Transilvani } \\
\text { a }\end{array}$ & $\begin{array}{l}\text { CEC } \\
\text { Bank }\end{array}$ & $\begin{array}{l}\text { UniCredit Tiriac } \\
\text { Bank Romania }\end{array}$ & $\begin{array}{l}\text { Raiffeisen } \\
\text { Bank Romania }\end{array}$ & $\begin{array}{l}\text { Alpha Bank } \\
\text { Romania }\end{array}$ & $\begin{array}{l}\text { Bancpost } \\
\text { Romania }\end{array}$ \\
\hline TTC PD & $3.41 \%$ & $2.96 \%$ & $1.30 \%$ & $2.01 \%$ & $0.19 \%$ & $3.83 \%$ & $0.88 \%$ & $1.76 \%$ \\
$\begin{array}{l}\text { TTC S\&P } \\
\text { Rating }\end{array}$ & $\mathrm{B}+$ & $\mathrm{B}+$ & $\mathrm{BB}$ & $\mathrm{BB}-$ & $\mathrm{BBB}+$ & $\mathrm{B}+$ & $\mathrm{BB}$ & $\mathrm{BB}-$ \\
\hline
\end{tabular}

Table 4. The banks' Through-the-Cycle default probabilities and mapping to S\&P ratings. (Continue)

\begin{tabular}{|c|c|c|c|c|c|c|c|c|c|c|}
\hline & \multicolumn{10}{|c|}{ Smaller Banks } \\
\hline & $\begin{array}{l}\text { Piraeus } \\
\text { Bank } \\
\text { Romania } \\
\end{array}$ & $\begin{array}{l}\text { RBS } \\
\text { Bank } \\
\text { Romania }\end{array}$ & $\begin{array}{l}\text { Intesa } \\
\text { Sanpaolo Bank } \\
\text { Romania } \\
\end{array}$ & $\begin{array}{l}\text { Credit Europe } \\
\text { Bank } \\
\text { Romania } \\
\end{array}$ & $\begin{array}{l}\text { Banca } \\
\text { Comerciala } \\
\text { Carpatica }\end{array}$ & $\begin{array}{l}\text { OTP } \\
\text { Bank } \\
\text { Romania }\end{array}$ & $\begin{array}{l}\text { Eximban } \\
\mathbf{k} \\
\text { Romania }\end{array}$ & $\begin{array}{l}\text { ProCredit } \\
\text { Bank } \\
\text { Romania } \\
\end{array}$ & $\begin{array}{l}\text { Bank } \\
\text { Leumi } \\
\text { Romania }\end{array}$ & $\begin{array}{l}\text { Nexteban } \\
\mathbf{k} \\
\text { Romania }\end{array}$ \\
\hline $\begin{array}{l}\text { TTC } \\
\text { PD }\end{array}$ & $0.22 \%$ & $2.64 \%$ & $1.48 \%$ & $1.81 \%$ & $1.58 \%$ & $0.34 \%$ & $2.36 \%$ & $2.07 \%$ & $1.34 \%$ & $2.42 \%$ \\
\hline $\begin{array}{l}\text { TTC } \\
\text { S\&P } \\
\text { Rating }\end{array}$ & BBB & BB- & BB- & BB- & BB- & BBB- & BB- & BB- & $\mathrm{BB}$ & BB- \\
\hline
\end{tabular}

Table 5. The portfolio's Point-in-Time and Through-the-Cycle default probabilities and mapping to S\&P ratings.

\begin{tabular}{lllllllll}
\hline \multicolumn{1}{l}{ PIT PD (default probability, expected in 1 year) } & & & TTC PD \\
\hline & $\mathbf{2 0 0 7}$ & $\mathbf{2 0 0 8}$ & $\mathbf{2 0 0 9}$ & $\mathbf{2 0 1 0}$ & $\mathbf{2 0 1 1}$ & $\mathbf{2 0 1 2}$ & $\mathbf{2 0 1 3}$ & T \\
\hline Average PIT PD on the portfolio & $0.17 \%$ & $0.10 \%$ & $6.28 \%$ & $4.28 \%$ & $1.06 \%$ & $0.34 \%$ & $0.48 \%$ & $1.88 \%$ \\
Mapping to S\&P Rating & BBB + & A- & B & B + & BB & BBB- & BB + & BB- \\
\hline
\end{tabular}

The Table 4 presents the expected punctual default probabilities estimated for each bank on a Through-the-Cycle (TTC) approach (where the TTC default probability covers in average approximate four years of Point-in-Time default probabilities), with exception to UniCredit Tiriac Bank Romania for which we have two years of prediction. The model results evidence that the smaller banks are perceived with lower credit risk. Moreover just few banks are assigned with investment grades. Looking to the Table 5, we notice a consistent trend in the assignment of the rating grades at portfolio level on a yearly basis, namely there are: good ratings before financial crisis (by 2008), the worst ratings in the years after $(2009,2010)$, then continuing with a recovery period. Altogether, the model estimates a default probability 
of $1.88 \%$ at portfolio level over through-the-cycle.

The Fig.7 - 12 present the default intensity curves for the first six banks of the Romanian banking system (by asset value), in order to evidence the empirical results on this hazard metric. The default intensity measure quantifies the corporate debt investors' hazard (respectively, the instant default probability) at receiving the banks' new accounting asset values. As far as the new accounting asset values are closer to the default barrier level, the investor's hazard rate is higher. The increased values of the hazard rate are directly evidenced by the default probabilities also. At a higher default probability the distance to default is lower, meaning that a small variation in the bank's accounting asset value forces toward a big increase in the default intensity.

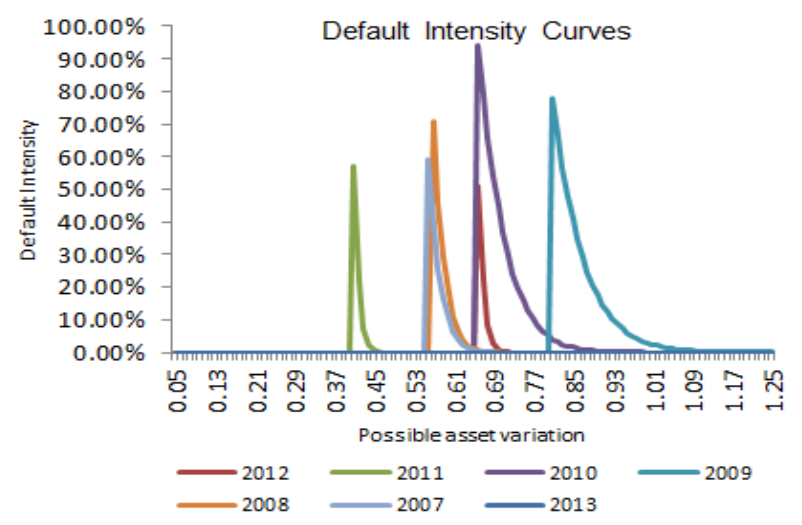

Figure 7. Banca Comerciala Romana.

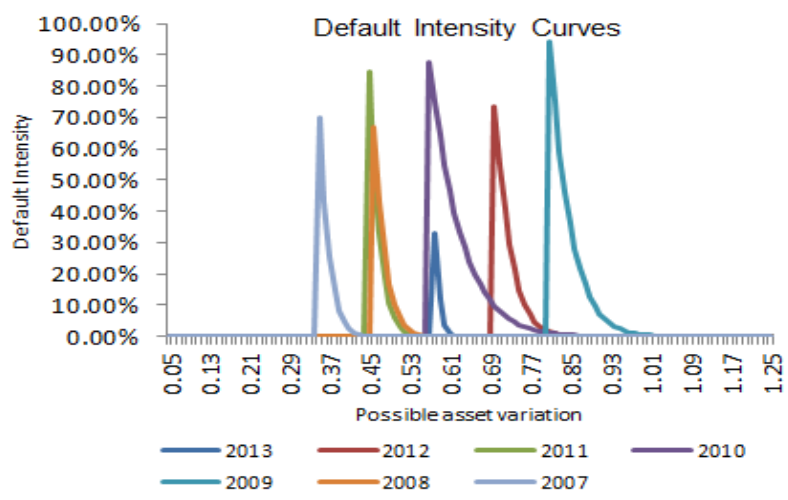

Figure 8. BRD Goup Societe Generale. Romania

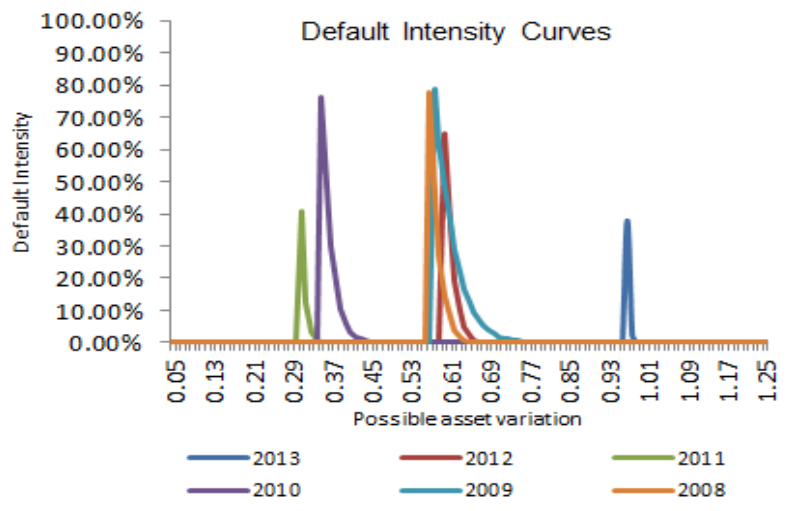

Figure 9. Banca Transilvania.

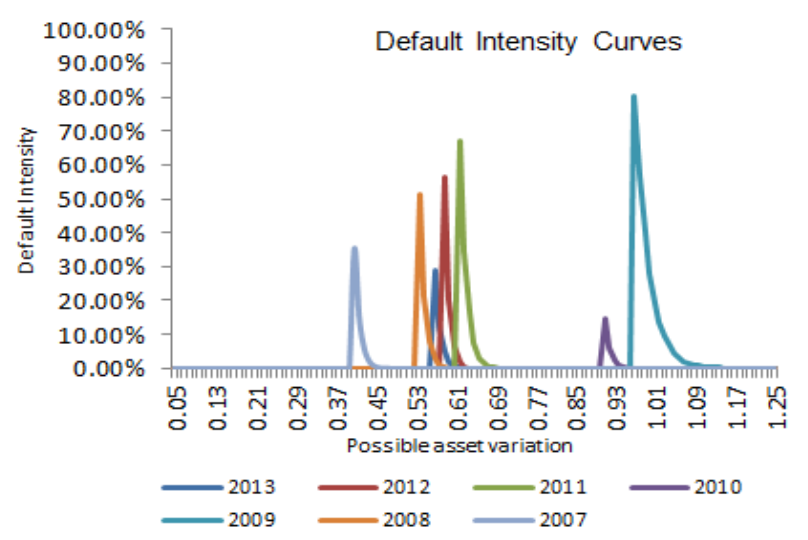

Figure 10. CEC Bank.

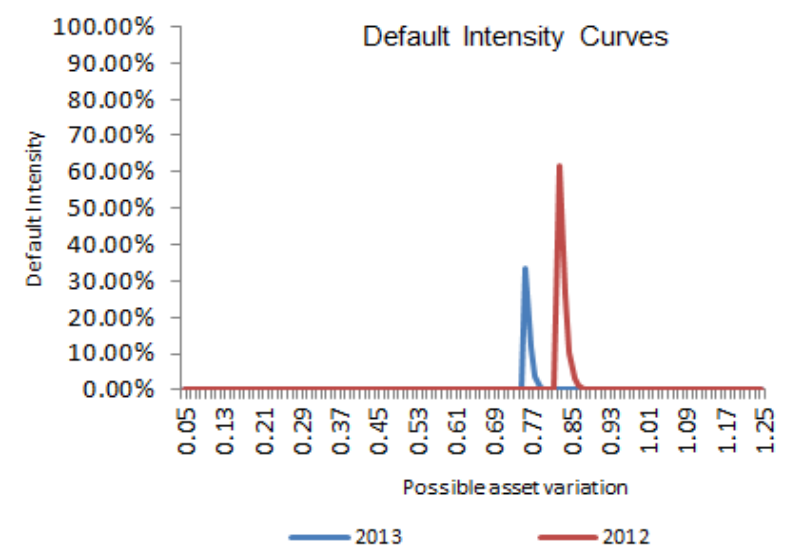

Figure 11. UniCredit Tiriac Bank. Romania

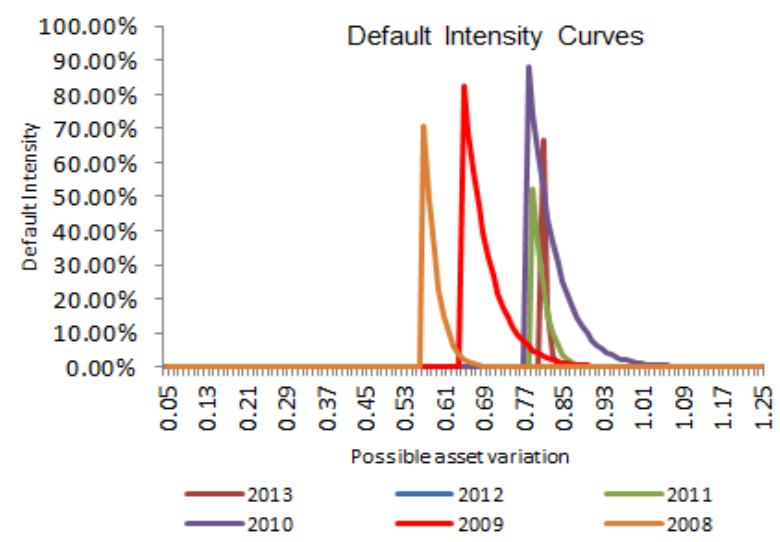

Figure 12. Raiffeisen Bank. Romania

\section{Conclusions}

[5] Duffie and Lando (2001) credit risk structural model with the assumptions of the asymmetric information avoids the constraints of the classical structural models that the default event is predictable and thus the short term credit risk spreads provided by the model are different than zero. As presented, the unpredictability of the default event is supported by the existence of the default intensity (the hazard rate) perceived by the corporate debt investors of the firm.

Such structural model can facilitate the creditworthiness assessment of the low default portfolios (i.e. the financial 
institutions).

According to our empirical evidence on the banks of the Romanian banking system, we evidence that:

- The model complies with the unpredictability assumption around the default time, given that the empirical evidence provides estimations of the default intensity.

- For the analyzed banks, the model offers plausible estimates related to the ordering of the annual default probability curves and default intensity curves.

- The maximum default probability curves are estimated for the years 2009 and 2010, these being consistent with the macroeconomic shocks that affected the Romanian economic activity during that period too.

- The model assesses the smaller banks slightly less risky than the bigger banks, based on the through-the-cycle analysis performed using their financial statements over the last Romanian business cycle.

- The model results provides big differences among the scale of default probability curves/ default intensity curves, both by comparison from year to year as well as among the smaller and bigger banks. We can address pros and cons related to the interpretation of this remark: Pros:

The model consistently reacts to the crisis period, and addresses the assumption of ex-post survival of the firm as an evidence of its better creditworthiness. The effects are even more prominent in the light of the different economic scale among the bigger and smaller banks (in advantage being perceived the smaller banks), as well as looking over a longer survival observation period from the impact of the macroeconomic shocks.

Cons:

The annual frequency of the financial statements used at the model calibration seems to be not enough in order to achieve a more robust modeling process. It deserves to be analyzed the model behavior by its calibration on semester financial statements time series in order to have longer data series and to understand if there are gained more robust results.

The distance to default is being computed as difference between the firm's asset value from previous year and the expected asset value to be accounted by the end of the current year. This assumption triggers that the banks assessment approach is rather dependent of their annual economic activity than their evolution on a whole business cycle. In case it is defined a distance to default depending of the asset value evolution on a whole business cycle, it is expected that this metric would better control the model overreaction in connection to the evolution scale of the bank's asset value.

In the light of the global financial crisis broken out in 2008, the international academic literature as well as professionals on the credit risk management and control working for prestigious international financial institutions (such as International Monetary Fund), point out the distinct importance of the new structural models with asymmetric information and their reconciliation with the reduced form models (see i.e. [4] Capuano and co. (2009)).

\section{References}

[1] R. Anderson, Y. Pan, S. Sundaresan, „Corporate Bond Yield Spreads and the Term Structure", Working Paper, CORE and Columbia Business School, 1992.

[2] R. Anderson, S. Sundaresan, „Design and Valuation of Debt Contracts", Review of Financial Studies 9, 37 - 68, 1996.

[3] F. Black, J.C. Cox, „Valuing Corporate Securities: Some Effects of Bond Indenture Provisions", Journal of Finance, 351 - 367, 1976.

[4] C. Capuano, et all, "Recent Advances in Credit Risk Modeling", International Monetary Fund, Working Paper, 2009.

[5] D. Duffie, D. Lando, „Term Structures of Credit Spreads with Incomplete Accounting Information", Econometrica 69(3), 633-664, 2001.

[6] D. Duffie, L.H. Pedersen, Singleton K.J., „Modeling Sovereign Yield Spreads: A Case Study of Russian Debt", Journal of Finance 58(1), 119-159, 2003.

[7] D. Duffie, K.J. Singleton, „Modeling Term Structures of Defaultable Bonds", Review of Financial Studies 12, 687-720, 1999.

[8] D. Duffie, K.J. Singleton, „Credit Risk: Pricing, Measurement and Management”, Princeton Series in Finance, 2003.

[9] H. Fan, S. Sundaresan, „Debt Valuation, Renegotiation, and Optimal Dividend Policy", Review of Financial Studies, 13, 1057-1099, 2000

[10] E. Fischer, R. Heinkel, J. Zechner, "Dynamic Capital Structure Choice: Theory and Tests", Joumal of Finance, 44, 19-40, 1989.

[11] H.E.Leland,„,Corporate Debt Value, Bond Covenants, and Optimal Capital Structure”, Journal of Finance 49, 1213 - 1252, 1994.

[12] H.E. Leland, „Agency Costs, Risk Management, and Capital Structure", Journal of Finance, 53, 1213-1242, 1998.

[13] H.E. Leland, K. Toft, „Optimal Capital Structure, Endogenous Bankruptcy and the Term Structure of Credit Spreads", Journal of Finance 51, 987 - 1019, 1996.

[14] P. Mella-Barral, W. Perraudin, „Strategic Debt Service”, Journal of Finance 52, 531 - 556, 1997.

[15] P. Mella-Barral, "Dynamics of Default and Debt Reorganization", Review of Financial Studies, 12, 535-578, 1999.

[16] R.C. Merton, „On the Pricing of Corporate Debt: The Risk Structure of Interest Rates", Journal of Finance 29, 449 - 470, 1974.

[17] H. Uhrig, "Endogenous Bankruptcy when Issuance is Costly", Working Paper, Department of Finance, University of Mannheim, 1998.

[18] S. M. Vlad, „Empirical Evidence: Complete vs. Incomplete Information Credit Risk Models", Journal of Economic Computation and Economic Cybernetics Studies and Research $2,206-218,2010$. 
[19] G. Ruxanda, S. M. Vlad, "Evaluarea bancilor BCR, BRD folosind un model structural de risc de credit cu informatie asimetrica", Journal of Economic Computation and Economic Cybernetics Studies and Research, RO 3 - 4, 5 - 16, 2012. 